\title{
THE EXISTENCE OF GOD IN A DOGMATIC APPROACH
}

\author{
Zaprulkhan \\ IAIN Syaikh Abdurrahman Siddik Bangka Belitung, Indonesia \\ zaprulkhan_zahra@yahoo.co.id
}

\begin{abstract}
In the perspective of religious history, humans are not only homo sapiens, rational thinking beings, but also homo religiosus, religious beings who always depend on and worship God. As bomo religiosus, humans always try to find meaning in their lives by connecting it to the ultimate reality which he calls God. The search for meaning is what drives humans to always build their perspectives, conceptions, and religious experiences about God. In the view of some experts, the initial construction built by humans religiously is through their perception of God. Man's perception of God that is packaged and taught in that religion, is indeed built on the basis of God's revelation, so as to obtain a dogmatically solid foundation. This paper, will discuss the existence of God which is sourced from revelations namely the Qur'an dogmatically.

[Dalam perspektif sejarah agama, manusia tidak hanya sebagai bomo sapiens, makhluk berpikir rasional, melainkan juga sebagai homo religiosus, makhluk yang senantiasa bergantung dan menyembah kepada Tuhan. Sebagai homo religiosus, manusia selalu mencoba menemukan makna dalam kehidupannya dengan mengaitkannya realitas tertinggi yang disebut dengan Tuhan. Pencarian makna inilah yang mendorong manusia untuk selalu membangun perspektif-perspektif, konsepsikonsepsi, dan pengalaman religiusnya tentang Tuhan. Dalam pandangan beberapa ahli, konstruksi awal yang dibangun oleh manusia secara religius adalah melalui persepsi mereka tentang Tuhan. Persepsi manusia tentang Tuhan yang dikemas dan diajarkan dalam agama itu, memang dibangun atas dasar wahyu Allah, sehingga memperoleh landasan dogmatis yang kokoh. Tulisan ini, akan membahas tentang eksistensi Tuhan yang bersumber dari wahyu yaitu Al-Qur'an secara dogmatis.]
\end{abstract}

Keywords: Existence, God, Dogmatic Approach 


\section{A. Introduction}

In the study of the classical Greek historian, Plutarch, it was found that human devotion to God the Creator is something that is essential as well as an existential need of every human being. In his study, Plutarch found that no one can find a city that does not have worship or a city that does not teach worship to its inhabitants. ${ }^{1}$

This fact can be seen also in the historical-sociological intellectual exploration conducted by Karen Armstrong about the search for humanity against God. From classical times to modern times, in Armstrong's search it turns out that every human being always constructs the concept of God. It is done by theologians, philosophers, Sufis, or reformers. ${ }^{2}$ Even in his latest work, The Case for God, Karen Armstrong paints impressively about the human search for the existence of God from the era of thirty thousand years $\mathrm{BC}$ to the contemporary era today. ${ }^{3}$

In the perspective of religious history, humans are not only homo sapiens, rational thinking beings, but also homo religiosus, religious beings who always depend on and worship God. As homo religiosus, humans always try to find meaning in their lives by connecting it to the ultimate reality which he calls God. The search for meaning is what drives humans to always build their perspectives, conceptions and religious experiences about God.

According to Wilhelm Schmidt's research, at the beginning of human history, humans created a God who was the First Cause for all things and the Lord of heaven and earth. He was not represented by any description and did not have a temple or priest who served him. He is too noble for inadequate human worship. ${ }^{4}$ As Wilhelm Schmidt revealed that in the beginning of his life, humans had already constructed construction about God as the Ruler of the Universe and the First Cause, either through their perceptions, either through philosophical conceptions, or even based on a sense of experience in contact with transcendent reality. Interestingly, in Schmidt's research it was found that the concept of God Almighty was one of the

${ }^{1}$ Ahmad Bahjat, Mengenal Allah, trans. by: M. Abdul Ghoffar (Bandung: Pustaka Hidayah, 1998), p.

2 See Karen Armstrong, A History of God (London: Vintage Books, 1999).

${ }^{3}$ See Karen Armstrong, The Case for God (London: The Bodley Head, 2009).

${ }^{4}$ Karen Amstrong, Sejarah Tuhan, trans. by: Zaimul Am (Bandung: Mizan, 2004), p. 27. 
The Existence of God in A Dogmatic Approach

oldest ideas developed by humans to explain the mysteries and tragedies of life. This is what is called a primitive monotheism. ${ }^{5}$

In Musa Asy'arie's view, the initial construction constructed by humans religiously was through their perception of God. Human perception of God is shaped by religion through the practice of practicing worship to God, which is governed in detail and operationally by religion. Through the religious worship ceremony, a believer is expected to have a perception of the God he worshiped. ${ }^{6}$

Man's perception of God that is packaged and taught in that religion, is indeed built on the basis of God's revelation, so as to obtain a dogmatically solid foundation. At this point, we will frame God's perception through arguments about God's dogmatic existence which is based on revelation or scripture. This dogmatic discourse about God, will discuss the existence of God that comes from the revelation of the Qur'an logically.

\section{B. The Dogmatic Existence of God}

Let's look at some of the Qur'anic dogmatic arguments about the existence of God. First, proof of creation. The demonstrative argument of this evidence is that the existence of the whole creation proves the existence of a Creator. Allah SWT said: "Were they created without anything or were they created (themselves)? Or have they created the heavens and the earth ?; Actually they do not believe (what they say) (Surah Ath-Thur 52: 3536). ${ }^{7}$

Verses 35 and 36 above are one proof of the form and oneness of Allah SWT. Being and existence which are 'possible' in nature, that is, whether or not they canlike humans-certainly make it happen. Because how can it come into being if nothing has existed before? If so, there must be something that manifests and creates all these sentient beings. He is God the Creator. ${ }^{8}$

\footnotetext{
${ }^{5}$ Ibid., p. 27-28.

${ }^{6}$ Musa Asy'arie, Filsafat Islam Sunnah Nabi Dalam Berpikir (Yogyakarta: LESFI, 2017), p. 165.

${ }^{7}$ Ash-Shallabi, Ali Muhammad Ash-Shallabi, Iman kepada Allah, trans. by: Umar Mujtahid (Jakarta: Umul Qura, 2014), p. 70.

${ }^{8}$ M. Quraish Shihab, Tafsir Al-Misbah, Vol. 13 (Jakarta: Lentera Hati, 2002), p. 391.
} 
Therefore, the form of the Creator is certain. He also must be one, because the Creator of the universe is only He. If there is another Creator, surely in such a harmonious and consistent work will experience chaos and destruction. Because of course each Almighty Creator does what he wants without interference from other parties. The harmony and consistency of the universe shows how His Creator is One, All-Powerful, and All-knowing. ${ }^{9}$

If we examine, in the above verse, the Qur'an states to them, "you were created". This is a reality that you cannot deny. Likewise heaven and earth are both clearly created. As it is embedded in reason, something must have a cause. A camel herder in the desert will say, "Camel dung shows the camel and footprints indicate walking." Then what about the sky with its constellations, the earth with its broad valleys? It all shows the existence of the All-Knowing, the All-Seeing.

The existence of a Creator is also known by great scientists, researchers of life, and living things. A scientist once said, "God is the Most Azali, the Most Great, the Most Knowing of all things, the Almighty over all things, the beauties of His creation are clearly visible to me that makes me stunned and confused. The power, wisdom, and beauty that He embodies in all of His creation, from the small to the big."

This is what the verse above implies, and this is what scientists know as the law of causality. This law states, a possibility cannot create itself from nothing. Because based on his nature, he does not have enough cause for his existence. Nor can he create anything freely, because he cannot give or rule in the least for others. With this law, scholars from the past until now have denied the opinion of some people who deny the existence of a Creator. ${ }^{10}$

Second, the evidence in all corners of heaven and earth. Allah SWT said: "We will show them our signs (power) in all regions of the earth and in themselves, until it is clear to them that the Qur'an is true. Is it not enough that your Lord is a witness of all things" (QS. Fushshilat 41: 53).

\footnotetext{
${ }^{9}$ Ibid., p. 392.

${ }^{10}$ Ash-Shallabi, Iman kepada Allah, p. 70-72.
} 
The Existence of God in A Dogmatic Approach

The Word of God, "We will show them our signs (authority) in all regions of the earth", namely the signs of His unity and power. The sentence, "in all regions of the earth", that is, over the heavens and the earth, such as the sun, moon, stars, day, night, wind, rain, lightning, plants and other miracles of His creation.

Scientists' discussion of scientific miracles in the Qur'an shows signs of God's power in various corners of the earth and earth, including:

First, oxygen levels are running low in high places. Allah SWT said: "Whoever Allah wills will give him instructions, surely he will expand his chest to (embrace religion) Islam. and whoever God wants his error, surely Allah makes his chest tight again narrow, as if he were climbing the sky. That is how Allah inflicts torment on those who do not believe" (Qur'an, 6:125).

This verse states, when a person rises higher in the air, his chest will constrict and feel suffocated. This is a scientific fact that shows that oxygen levels become thinner as we rise to altitude, as is air pressure. These two factors make a person feel short of breath.

Second, the movement of stars and planets in their rotational lines. People used to think that the earth was the center of the solar system. The sun, moon and stars rotate around the earth. The stars are considered constant throughout the year until they are called "silent". Then in Galileo's time, the view emerged that the earth revolved around the sun, and the sun was the center of the solar system.

Long before that, the Koran rejected all opinions which state that nature has a permanent center. Allah SWT explains: "And each one circulates in its path" (Surah Yasin 36: 40).

Scientists further found that the positions and lines of the star crossing were not originating, because each planet and star had been placed in a very precise crossing line, so that it did not cause a large gravitational force, and did not cause the powerful thrust caused by the planet's rotation so that it caused natural instability. Cross lines have been determined for each planet to provide a balance between the many forces that exist. Scientists have also found the distances of star clusters, precisely according to the series of calculations. So, how can an Arab Jabiliyab who sees stars scattered in 
the sky know for themselves that in the positions of each star there is something extraordinarily large?

Third, the rotation of the earth and mountains. Allah SWT says: "(That is) the work of Allah which makes everything firmly established" (Surah An-Naml 27: 88).

In the past, people thought the earth and mountains were stationary, to the point that mountains were made similes because of their solidity. Next the Qur'an came to convey something not as it was known and which had been implanted in the minds of men. The Qur'an discusses natural phenomena, such as mountains that run like clouds. In other words, mountains are like clouds. Because the cloud does not move by itself, and only moves when there is a push to move, that is the wind, like that of a mountain.

The mountain does not move by itself, because the mountain functions as a peg of the earth so as not to shake. The movement of mountains follows the movement of the earth. The earth moves and rotates. If it's not like that, then how can a mountain be called walking like a cloud. This is a masterpiece of God who created everything perfectly. That's when solid conviction arises. ${ }^{11}$

Likewise, from satellite recordings, evidence is obtained that the Arabian Peninsula and its mountains move closer to Iran a few inches each year. Previously, about five million years ago the Arabian Peninsula moved apart from Africa and formed the Red Sea. Around the area of Somalia along the East to South coast is currently in a slow process of separation and has formed a "Cleft Valley" that runs south through a row of African lakes. That seems to be what is meant by the above verse by walking the mountains as the clouds walk. ${ }^{12}$

Fourth, the bulkhead between two seas. Allah SWT said: "He let the two oceans flow, both of which then meet. Between the two there are limits that are not exceeded respectively. Then which of your Lord's favors did you lie to? From them came pearls and marjans" (Surah ArRahman 55: 19-22).

11 Ibid., p. 77-80

12 M. Quraish Shihab, Mukjižat Al-Qur'an (Bandung: Mizan, 1998), p. 187-188. 
The Existence of God in A Dogmatic Approach

This verse discusses two seas that meet in one place, but between them there is a real barrier. This verse deals with two intrinsic salty oceans, not lakes or rivers, because it says "From both pearls and marjans come out".

Marjan is a red pearl that is only obtained from the salty sea. Thus, the above verse talks about a partition (barrier wall) that is essential between two salty seas at the meeting place of the two. Generally, two seas meet in the strait, because if there is no strait, of course there is no need to be called two seas, but one ocean.

The information conveyed by this verse is very strange according to human knowledge, because based on the facts circulating, the water meets each other without any insulation. In the past, no one knew this fact and it never crossed the mind, until it was finally revealed in 1962. The astonishing facts conveyed by the Qur'an were also proven.

Fifth, the ground moves and the volume increases due to rain. Allah SWT said: "And you see the earth is dry, Then when We have sent water on it, live the earth and be fertile and grow a variety of beautiful plants" (QS. Al-Haji 22: 5).

Science confirms, the earth really moves because of the rain. Grains, roots, microbes, and bacteria all start from movement, cell division, water absorption, entry of food juices arranged in a unit with diminished linkages, but with more numbers and larger shapes. When the soil's pores are filled with water, the soil will move into smaller parts. From there, the process of increasing the volume of small pieces of land occurs. Furthermore, earthworms play the role of splitting the cracks of the soil and eating large amounts of soil that are attached and subsequently released in the form of cracks.

All of these processes further increase soil volume. The miniature form of this process can be seen by mixing yeast into the dough and enlarging the shape of the dough that occurs due to the activity of yeast cells. From the ground, there are a lot of activities like this. From this explanation, we know the existence of harmony known to science and the explanation conveyed by the Qur'an. ${ }^{13}$

\footnotetext{
13 Ash-Shallabi, Iman kepada Allah, p. 80-82.
} 
Third, proof in humans. Allah SWT said: "And (also) to yourself. Do you not then pay attention?" (Surah Adzariyat 61: 21).

The closest to humans is himself. For this reason, Allah formed the form and created it from a drop of water (sperm), inviting humans to reflect on and think about the nature of themselves. When someone thinks of himself, surely there will be clear signs of divinity, the light of faith emerges, the darkness of doubt disappears, and the darkness of ignorance disappears in him. Because when people want to reflect on themselves, surely they will find strong evidence of the arrangement and evidence of the oneness of Allah SWT on him. Furthermore, he will realize and testify to the existence of the Regulator, the All-Shower and Guiding the straight path to get to Him. ${ }^{14}$

Fourth, proof of guidance. Allah SW'T said: "Moses said:" Our Lord is (God) Who has given each form of event something, Then gave bim instructions" (Surah Thaha 20: 50).

What is meant here is the creation and formation in accordance with a creature, as well as the instinct for everything needed in life, food, drink, how to breed and all other actions.

Al-Hadi (the All-Providing Guidance) is one of the names of Allah that shows and tells His servants the way to have faith in Him, acknowledge His uluhiyah, ways to foster life, and know the rules of life. Even Allah Almighty gives instinct to birds, animals, insects and wild animals for the good that is needed, livelihoods, warnings against all that is harmful and destructive. ${ }^{15}$

Regarding humans, there are several levels of guidance that Allah gives to them. His first level of guidance is His gift in the form of the instinctive potential that is obtained from birth, such as the cry of a baby before his eyes open. This cry is a gift from God to him as a guide, so that those around him know that he exists and lives and needs help.

Guidance or God's second instruction is the five senses. The first level of guidance (instinct) is limited to the creation of impulse to find the things needed. 
The Existence of God in A Dogmatic Approach

Instinct is not able to achieve anything that is outside the body of the owner of the instinct, at the time of his need to achieve something that is outside him. Once again humans need guidance and this time God bestows His instructions in the form of the five senses.

However, no matter how sharp and sensitive the ability of the human senses, often the results obtained do not reflect the true nature. No matter how sharp a person's eyes he will see a stick which is straightened to bend in water. What rectifies the error of the five senses is Allah's third instruction, reason. The mind that coordinates all of the information obtained by the senses then makes conclusions that are more or less can differ from the results of the sensory information.

But even though the guidance of reason is very important and valuable, it turns out that it only functions within certain limits and is unable to guide humans out of the reach of the physical realm. The field of operation is the real field of nature and even in this field human beings are rarely deceived by the conclusions of reason so that reason is not a guarantee regarding all the coveted truths. ${ }^{16}$

Reason can be likened to a float. He can save someone who is not good at swimming from being washed away in a swimming pool, or even in the middle of a calm sea. But if the waves have been blaring, or come insistent as high as a mountain, then when that is good at swimming and who is not smart the situation will be the same. At that time, they all not only needed a buoy, but something that exceeded the buoy. Therefore, humans need instructions that go beyond the direction of reason, while correcting errors in certain fields. The guidance meant is religious guidance.

While scholars divide religious instructions to two kinds of instructions. First, the instructions towards worldly and $u$ khrawi happiness. Quite a number of verses use the root word "bidayat" which contains this meaning, for example: "And verily you (Muhammad) give directions to the straight path" (QS. Ash-Shura 42: 52); ${ }^{17}$

Second, the instructions and the ability to carry out the contents of these instructions. This cannot be done except Allah SWT. Because of this he stressed that:

${ }^{16}$ M. Quraish Shihab, Menyingkap Tabir Ilabi (Jakarta: Lentera Hati, 1999), p. 420-421.

${ }^{17}$ M. Quraish Shihab, Tafsir Al-Misbah Vol. 1 (Jakarta: Lentera Hati, 2002), p. 62. 
"Verily, you (Muhammad) will not be able to give guidance (even though) to the person you love, but Allah gives guidance to the person He wants" (Qur'an, Al-Qashash 28: 56).

While God's guidance is in the form of instincts for various animals, let's look at the amazing phenomenon of bees. In the Qur'an, Allah says: "And your Lord revealed to the bees:" Make hives in the hills, in the trees of wood, and in places that are made of men ". Then eat from each fruit and take the path of your Lord which has been facilitated (for you). From the belly of the bee to the outside drink (boney) of various colors, inside there is a cure for bumans. Surely in that there really is a sign (the greatness of God) for those who think" (QS. An-Nah 16: 6869).

Watch for bees! Note also his efforts to make honey and hexagon-shaped nests. The hexagon is the most perfect, best and stinging shape of the coco. That is the trail of creation, inspiration and instinct that God has given to bees. Next consider how well the bee fulfills the inspiration that God has given it to its first step in making a hive. After the hive is formed, the bee comes out to look for food in the fruit after which it returns to the hive, because the Rabb orders it to first make a hive. After that look for food, take the path that has been facilitated by God without the slightest difficulty, after looking for food back to the nest.

One amazing thing, bees have a leader called the queen bee. Without the existence of this queen, bees cannot go in and out of the hive, do not work and find food. The command of the queen bee is obeyed and heard. The queen gave more commands and prohibitions, all of them obeying her orders, following the opinions expressed, like the king regulating the affairs of the people. When the bee army returns, the queen stands in front of the beehive's doors, not letting a single bee throng other bees or overtake it, one by one entering the hive without crushing, colliding, or stacking. Just as an army commander did when he arrived at a narrow crossing and could only be passed by one army at a time.

Anyone must be amazed when contemplating the conditions, methods, instincts, unity, discipline and kingdom of bees that are so neatly arranged, and certain jobs that are charged to each bee. Also surely know, this extraordinary ability is 
The Existence of God in A Dogmatic Approach

certainly beyond the ability of bees, not from the bees themselves. Because the work that is so neat and disciplined is very perfect.

So, who gives instincts to bees to do all that, has such character, who gives bees such instructions? Who could reduce the liquid to bees, where when taken by bees will be converted into pure honey with a variety of colors that are very sweet, delicious, and bring benefits? He is Allah SWT.18

Fifth, evidence of a neat universe. Proof of the existence of God through the regularity of the universe is one of the issues that is quite broadly discussed in the Qur'an. In this context, we will see a verse of the Qur'an and its explanation of the harmony of the universe as proof of the existence of God. The verse is in the Surah Al-Anbiya, verse 22, which is: "If there were in heaven and on earth gods besides Allah, surely both of them would have been destroyed perish. Then the Most Holy God who has 'Arsy than what they attribute" (QS. Al-Anbiya 21: 22). ${ }^{19}$

In this verse, it is very clear that such an argument is a rational argument, which asks us to realize that, because the heavens and the earth are in good order, surely there will be no gods but the One God. In terms of logic, this is called "the syllogism of exceptions". Those who know logic, know that syllogism has two types: the exclusion syllogism and the conjunctive syllogism. In the syllogism of exceptions, there is a correlation between two things, then one of them is proven. It has special forms, as explained in logic books.

For example, people say, "If the sun has risen, it is daytime", from which they conclude that the sun has risen. Or they say, "Now is not daytime" from which they conclude that the sun has not yet risen. This is a common example that is often used by logics. Here, there is also a correlation between polytheism and the destruction of heaven and earth. If there is more than one god, surely heaven and earth will be in chaos, just like the sun at noon. However, no other problems are mentioned about what happened to heaven and earth, and whether there are many gods.

18 Ash-Shallabi, Iman kepada Allah, p. 89-90. Lihat juga M. Quraish Shihab, Dia Di Mana-Mana (Jakarta: Lentera Hati, 2004), p. 299-303.

19 Ash-Shallabi, Iman kepada Allah, p. 93. 
Again, logics say that there is a hidden part of a syllogism. Sometimes conclusions are made in such a way that when a premise is mentioned, another premise (an induction usually consists of two premises) automatically arises in the mind and does not need to be stated specifically. Therefore, it is called the "hidden premise", although it does not exist.

In this case, the exception was not stated in the discussion. He should have said, "But they are not" to end the verse mentioned. So, the conclusion is "Therefore, there are no gods except God Almighty." However, as you have seen, these exceptions and results are clear, namely that heaven and earth exist and are in an orderly state. Therefore, by itself it can be said that the two are not in a state of chaos. This brings us to the conclusion that there is no god who rules both of them except Allah SWT. 20

In the perspective of interpretation, the argument of the above verse is explained in the form of qiyas istitsnai, i.e. the second part of the qiyas arranged in the "exclusion" proposition is removed to show eloquence and discussion. So, in fact the complete form of the arrangement of propositions is as follows: if there is a god other than Allah, then the heavens and the earth (symbols of all realms of existence) will be destroyed; however, this did not happen. Therefore, there is no god but Allah SWT. ${ }^{21}$ That is the exclusion syllogism argument.

Sixth, proof through human nature. Associated with evidence through human nature, there is a verse that forms the basis of the verse verses in surah Ar-Rum verse 30: "Then face your face (the Prophet Muhammad) to the religion (Islam) in a straight state. (Keep defending) the nature of Allah who created mankind (ie fitrah) Allah. There is no change in God's creation (ie fitrah). That is a straight religion, but most people do not know (ie do not have the right knowledge)" (Surah Ar-Rum 30: 30). ${ }^{22}$

The word fitrah is an infinitive type, which indicates the type of creation, although it is usually used with regard to humans. Usually he refers to something that 86.

${ }^{20}$ Taqi Mishbah Yazdi, Filsafat Taubid, trans. by: M. Habib Wijaksana (Bandung: Arasy, 2003), p. 85-

${ }^{21}$ Muhammad Nur Jabir, Dalil Pembuktian Tuban (Makasar: Chamran Press, 2018), p. 217.

22 M. Quraish Shihab, Al-Qur'an dan Maknanya (Jakarta: Lentera hati, 2010), p. 407. 
The Existence of God in A Dogmatic Approach

is human nature. It is a gift from God and cannot be learned and can be said to be general to all individual human beings. Therefore, it includes the tendency of all views and gifts from God. ${ }^{23}$

In general, the word fitrab includes the following meanings:

1. Meaning which shows that seeking Allah SWT is one of human's innate desires. The evidence that shows this statement is that humans, throughout history, and do not care about ethnic, geographical, and educational differences are in search of Allah SWT. ${ }^{24}$

Godliness is a fitrawi tendency in humans. The evidence of this assumption can be seen in humanity's constant search for God throughout human history. Apart from cultural, geographical, ethnic, and national diversity, belief in God as the creator of the universe is always present in humans. ${ }^{25}$

2. Meaning which shows that the introduction of Allah is a natural type of knowledge, by which we mean two types of knowledge: innate knowledge and intuitive knowledge.

a) What we mean by innate knowledge about Allah SWT is the fact that human reason does not need to over-exert themselves in believing in the existence of Allah SWT, because something that is very easily realized that human existence and all other natural phenomena require Allah SWT. So, there must be a God who does not need, who can meet their own needs.

b) What we mean by intuitive knowledge about Allah SWT is the fact that the human heart has a deep relationship with its Creator. When looking deeply into his heart, humans will see the relationship. However, most people pay little attention to, if any, this heartfelt relationship, especially when too busy with their daily work. However, when their hopes are taken from everything and separated from all means, they can realize the relationship.

${ }^{23}$ Mishbah Yazdi, Filsafat Taubid, p. 42.

${ }^{24}$ Ibid.

${ }^{25}$ Muhammad Nur Jabir, Dalil Pembuktian Tuban, p. 115. 
3. Meaning which shows that worship to Allah SWT is an innate tendency and that man is driven by his nature which demands that he worship Allah, pay homage, and obey Him. ${ }^{26}$

4. Divine fitrah means monotheism is a tendency to fitrawi and is internal. Man performs rituals of worship based on this nature and submits himself when confronted with Himself namely His Lord. ${ }^{27}$

So when we want to use the term fitrah regarding God, we can use the following two terms:

1. The purpose of knowledge of nature toward God is a form of knowledge that is badibi and does not require a hard effort from the human mind in providing an assessment of God's existence. It is very easy to understand that the existence of nature is limited and dependent, so it needs to be in an existence that does not depend on anything that will create itself. However, this knowledge is a correspondence knowledge. The argument is very clear and does not really require exploration of reason. This knowledge is called fitrawi knowledge.

2. The purpose of the knowledge of nature toward God is that humans have the knowledge of the presence of the creator who created himself. Every human being is created with this nature, namely with the science of presence. The science of presence is a Divine mandate that has been placed in human beings. This is what is meant by hadith: Every child is born with nature. In another hadith added "on the nature of Tawhid". That is, every child is born with the nature of monotheism. ${ }^{28}$

In surah Ar-Rum verse 30 above, fitrah is the basis of God's creation where humans are created according to the fitrah. Fitrah is the tendency to worship God and surrender to God. This tendency is rooted in human nature. Therefore, every human being naturally wants to draw closer to God and worship Him. Then, the tendency to do wrong comes from ignorance (ignorant) or wrong in finding the form he wants.

${ }^{26}$ Mihbah Yazdi, Filsafat Taubid, p. 42-43.

${ }_{27}$ Muhammad Nur Jabir, Dalil Pembuktian Tuban, p. 116.

${ }^{28}$ Ibid., p. 116-117. 
The Existence of God in A Dogmatic Approach

This is what causes humans to always look for other than Himself, where when he arrived at it, he was not satisfied and finally left what he achieved. Because of that, it is truly an expression that states that humans are like birds that always fly to infinite perfection that is vast and infinite. The limitations of this material nature will not be able to accommodate an unlimited breadth of the soul.

\section{Concluding Remarks}

Based on the previous presentation, although in Surah Ar-Rum verse 30 it does not directly address the issue of "Tawheed", but worship of God is considered as fitrah. Fitrawi worship of God is the norm of intrinsic knowledge about God.

At its peak, human perfection can only be obtained through conscious action or through human effort and effort. Therefore, the way to strengthen the science of this presence is by effort and endeavor, worshiping with sincerity, being present with the heart, and fully committed to the Divine through absolute obedience without conditions and in any condition, so that he is to some degree of perfection-perfection human.

At this point, all the arguments about the existence of God that have been presented in this section are dogmatic-logical. That is, we build our perception of the existence of God by referring to a number of verses of the Qur'an that show the existence of God Almighty, Almighty as well as the Creator and Manager of His created universe. However, the verses of the Qur'an are explored using a logical approach, so that the evidence of God's existence can be understood and accepted logically. That is the dogmatic-logical argument from which we build our perception of the existence of God. 


\section{REFERENCES}

Armstrong, Karen. A History of God. London: Vintage Books, 1999.

----. Sejarah Tuhan. Terj. Zaimul Am. Bandung: Mizan, 2004.

----. The Case for God. London: The Bodley Head, 2009.

Ash-Shallabi, Ali Muhammad Ash-Shallabi, Iman kepada Allah. Terj. Umar Mujtahid. Jakarta: Umul Qura, 2014.

Asy’arie, Musa. Filsafat Islam Sunnah Nabi Dalam Berpikir. Yogyakarta: LESFI, 2017.

Bahjat, Ahmad. Mengenal Allah. Terj. M. Abdul Ghoffar. Bandung: Pustaka Hidayah, 1998.

Jabir, Muhammad Nur. Dalil Pembuktian Tuban. Makasar: Chamran Press, 2018.

Shihab, M. Quraish. Tafsir Al-Misbah Vol. 13. Jakarta: Lentera Hati, 2002.

----. Al-Qur'an dan Maknanya. Jakarta: Lentera hati, 2010.

----. Dia Di Mana-Mana. Jakarta: Lentera Hati, 2004.

----. Menyingkeap Tabir Ilahi. Jakarta: Lentera Hati, 1999.

----. Tafsir Al-Misbah Vol. 1. Jakarta: Lentera Hati, 2002.

----. Mukjizat Al-Qur'an. Bandung: Mizan, 1998.

Yazdi, Taqi Mishbah. Filsafat Taubid. Terj. M. Habib Wijaksana. Bandung: Arasy, 2003. 